\title{
A Review: Gurrent Status of Parenteral Amino Acid Therapy
}

\author{
H. GHadimi ${ }^{[47]}$ \\ Department of Pediatrics, Downstate Medical Center, State University Hospital, \\ Methodist Hospital of Brooklyn, Brooklyn, New York, USA
}

Intravenous glucose infusion is a ubiquitous commonplace on any hospital ward. Since its first use toward the end of the 19th Century [3], glucose has become the mainstay of parenteral nutrition. The signs and symptoms of glucose deficiency are clear and the requirements of the body are well defined. Analysis of blood glucose is routinely available and results are informative with regard to the intracellular state. Although the body often has considerable caloric reserve in the form of glycogen and fat, physicians are generally quick to respond with glucose infusion to any threatened caloric deficiency.

The situation with respect to amino acid therapy is entirely different. Requirements under parenteral conditions are unexplored, diagnosis of marginal deficiency is difficult, the quantitative method of analysis is sophisticated, and intravenous amino acid therapy is still a rarity in most institutions.

Elaboration of the extenuating circumstances hardly justifies our failures in the past, but may expedite the development of rational solutions.

A therapeutic armamentarium is generally developed in response to a clinical need arising out of a diagnostic entity. The diagnosis of advanced protein malnutrition (kwashiorkor) can be made on clinical grounds without supportive laboratory data. The condition is primarily an economic, regional problem which responds to oral protein intake. On the other hand, acute protein deficiency is in the present state of the art an ill defined entity based on circumstantial evidence. The diagnosis depends on such findings as history of protein deprivation, age of patient, and thus the relative significance of protein in the diet. Acute protein deficiency is often referred to as "early" or "marginal," but such terms belie its full clinical sig- nificance. One practical measure of gauging the potential of amino acid therapy is the growing number of indications for amino acid infusions in conjunction with hyperalimentation as well as the gratifying results achieved.

To put the entire subject in the proper perspective, a brief review of pertinent aspects of the protein economy is in order.

The "currency" used in the protein economy is free amino acids which reach the different tissues via the circulating plasma. The "capital" consists of intracellular free amino acids as well as bound amino acids in the form of protein. Whether cytoplasmic free amino acids are committed to protein synthesis within a given cell or can be totally mobilized to take part in protein synthesis elsewhere in the body is questionable. Breakdown of protein to supply free amino acid currency seems to be at the expense of tissue destruction, as judged by animal experiments. Adibi [1] has found that during 8-day starvation in rats the total amount of amino acids (free plus bound) per gram of muscle or liver was not affected by starvation, yet the weight of both tissues significantly decreased. Since there was no change in intracellular water content, the mobilization of amino acids from these tissues must have been at the expense of tissue breakdown. There thus appears to be no nitrogen "savings account" in the protein economy, and such terms as nitrogen "pool," "depot," or "reservoir" carry a misleading connotation of expendability.

On the anabolic side of the ledger, the protein economy is fundamentally affected by the type of tissues chosen for synthesis and the rate at which anabolic processes are carried out. The latter, based on studies on albumin synthesis, is depressed under conditions 
of protein starvation [36]. On the other hand, the body seems to be rather injudicious in assigning priorities for protein synthesis, particularly under conditions of starvation. For instance, in protracted infantile diarrhea with intake limited to dextrose solution, free amino acids bought so dearly from endogenous sources do not necessarily go into formation of digestive enzymes [4, 20] (i.e., disaccharidase) or the regeneration of intestinal mucosa [11], both of which are urgently needed for the restoration of normal digestive function. Admittedly, our knowledge regarding priorities for protein synthesis, both in health and disease, is quite rudimentary.

In further delineating the protein resources available to the body, the following salient data are helpful: (1) Only a small fraction of body nitrogen exists as free amino acids, and these are primarily located inside the cell rather than extracellular fluids. Of total body protein, 'free amino acids (in rats) are $0.5 \%$ [17], and plasma amino acids (in infants) only about $0.01 \%$. (2) There is wide variation in the free amino acid content of different tissues, both in terms of pattern and concentration. (3) Muscle consistently constitutes the largest single compartment of amino acids, both free and protein bound. In rats, $45 \%$ of body weight is made up of muscle [6], and about $57 \%$ of the total free amino acids are located in muscle [25]. (4) In humans, too, muscle is the largest protein-containing compartment, making up almost half the weight of the adult body [40]. In neonates, however, muscle constitutes only about $20-25 \%$ of the body weight [13]. (5) The total body protein resources also differ with age. In neonates, protein constitutes $11.6-12.4 \%$ of body weight [43], as compared with $14.5-18.8 \%$ in adults [44].

These considerations converge toward a number of conclusions of practical and clinical value.

\section{Newborns are Particularly Vulnerable to Protein Malnutrition}

Tissue richest in protein is relatively meager in neonates. At birth, skeletal muscle represents only $20-25 \%$ of the birth weight, and the gain in skeletal muscle from birth to the middle of the third decade of life is equal to the growth of all other organs, systems, and tissues combined [13]. Neonates are therefore exposed to the double stress of limited resources and voracious anabolic demands exceeding those of any other period of life.

\section{The Body Has No Protein Pool Analogous to Fat and Glycogen for Calories}

It is relevant to add here that while amino acids can be burned to provide calories, glucose cannot act as a precursor for essential amino acids.

\section{Biochemical Assessment of Acute or Marginal Protein Deficiency Still Remains Unsatisfactory}

Free amino acids of the plasma even when analyzed by elaborate quantitative technique add little information about the state of the protein economy, except under conditions of advanced deficiency [34]. The free amino acids, constituting about $0.01 \%$ of the total protein, can be readily adjusted through the breakdown of a relatively small amount of endogenous protein. In evaluation of individual plasma amino acid values, it should be borne in mind that the normal variation is often as much as 200-300\% (lysine, 1-4 mg; threonine, 1-3 mg), as compared with approximately $10 \%$ variation in blood electrolytes. Other biochemical parameters have been used to assess the state of protein nutrition. These include nitrogen balance, plasma albumin [31], plasma enzymes [37], urinary nitrogen [38], urinary excretion of hydroxyproline [27], urinary excretion of creatinine [39], Whitehead index [42] (ratio of hydroxyproline to creatinine), urea nitrogen to creatinine ratio [33], erythrocyte to plasma ratio of free amino acids [2], transferrin [24], bilirubin [19], cholesterol and its esters [28], ratio of essential to nonessential amino acids [29], blood serum protein retention [19]. Proper interpretation of most of these tests requires knowledge of "normal" values for a given individual. In any case, the existence of such a large number of tests indicates that no truly adequate procedure has yet been developed.

In spite of the inadequacy of diagnostic criteria for protein deficiency, the list of indications for parenteral amino acid therapy is rapidly growing. It is difficult to see why this potential has been so slow to be realized, and why amino acid therapy has not achieved acceptance analogous to that accorded to glucose, unless the problem is sought in the amino acid solutions themselves.

Since their introduction more than 3 decades ago, amino acid solutions for infusion have not been improved. Proteins with high essential amino acid content or high biological value by criteria of oral nutrition (i.e., casein, albumin, fibrin) were selected as mo- 
dels, and were hydrolyzed to provide solutions for intravenous administration. The motivation for selecting this approach may have been manufacturing expediency or erroneous analogy with oral protein nutrition. In any case, such hydrolysates proved to have a number of serious inherent drawbacks for parenteral use, when the liver and the gastrointestinal tract are by-passed.

\section{Glutamic Acid}

Most of the hydrolysates contain glutamic acid in levels sufficient to produce side effects such as nausea. The emetic effect of glutamate was documented as early as 1948 [22, 31]. However, the evanescent and protean effects of ingestion or injection of large amounts of this substance have been described only recently as a clinical entity $[18,30]$ and explained tentatively by us as transient acetylcholinosis [10]. Under normal conditions, glutamic acid is gradually released from ingested protein and is probably transaminated in the intestinal mucosa [26], with the resultant alanine reaching the liver. The situation is entirely different when a loading dose of glutamic acid is ingested or the substance is injected directly.

\section{Peptides}

As much as $30 \%$ of the nitrogen in protein hydrolysate may be in the form of peptides [16]. These substances have not been characterized, and may cause pyrogenic and allergic reactions. The incidence of side effects with protein hydrolysates has been reported to approach $4 \%$, as compared to under $0.3 \%$ with crystalline amino acids [16].

\section{$p \mathrm{H}$}

The titratable acidity of casein hydrolysate is 26.44 meq/liter for Amigen, 4\% [45], and $40.88 \mathrm{meq} /$ liter for Hyprotigen [46], 5\% [5]. Such a high level of titratable acidity is especially undesirable when the solution is administered to low birth weight neonates with limited buffering capacity and propensity to respiratory disease syndrome.

\section{Quantitative Inaccuracy}

Discrepancies between amino acid levels as claimed by manufacturer and as actually determined by quantitative technique have been found consistently, and have exceeded $100 \%$ in some instances [8]. Strangely enough, a product reported to be a solution of crystalline amino acids lists the concentrations on the label as "approximate."

\section{Irrational Composition}

There was no a priori reason to expect that the composition of casein or fibrin or egg protein would correspond to the relative amino acid proportions required by the body under conditions of parenteral alimentation. Indeed, our recent studies show consistent distortion of plasma amino acid patterns following administration of protein hydrolysates [8]. In Figure 1, the plasma aminogram of a low birth weight infant receiving $3 \mathrm{~g} / \mathrm{kg}$, body wt, of FreAmine is compared with values for cord blood. The base line for cord blood is provided by our earlier work [12], as well as by the findings of Scandinavian investigators [23]. The point at issue is not the remarkable agreement between work conducted on the two sides of the Atlantic, but the striking deviation from normal brought about by an amino acid mixture based on the proportions of egg protein (FreAmine). A distortion of such magnitude can hardly be considered innocuous, particularly in premature or low birth weight infants and in long term parenteral administration lasting weeks or even months. After all, aminoacidopathies-often associated with mental retardation-are also characterized by distorted plasma amino acid patterns. Seminal studies by Harper on amino acid toxicities and imbalance in rats [14] show that even under conditions of oral ingestion a proper amino acid balance is indispensable to normal body functioning.

\section{Ammonia}

Ammonia contamination of protein hydrolysates, amounting to $16-55 \mathrm{mg} / 100 \mathrm{ml}$, has recently been reported $[9,35]$. This startling finding seems to be accepted with as much equanimity as the original report of ammonia contamination of protein hydrolysate made by Webster et al. in 1957 [41], which has just come to our attention. In any case, the clinical entity described by Silvis et al. as "fatal hyperalimentation syndrome" [32] may well be explained by hyperammonemia resulting from injection of ammonia-containing solutions. The commercially available solution of synthetic L-amino acids (FreAmine) proclaimed to have negligible amounts of ammonia, apparently also causes hyperammonemia [15]. This is not surprising in view of the high glycine content of the preparation (approximately 20\% the total weight of amino acids). As early as 1956 it was reported that administration of high concentrations of glycine may lead to the development of hyperammonemia [7]. 


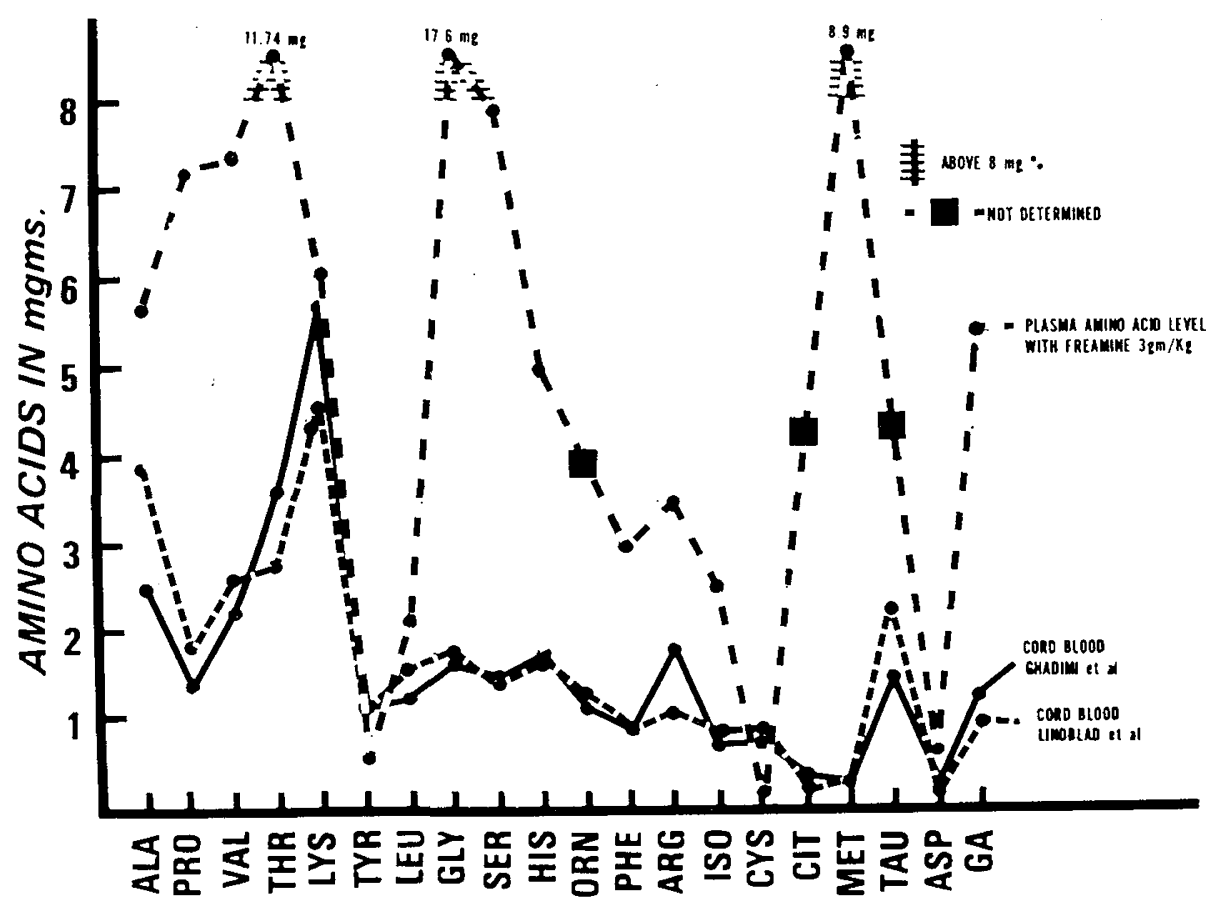

Fig. 1. Plasma aminogram of low birth weight infant during total parenteral alimentation with FreAmine $(3 \mathrm{~g} / \mathrm{kg}$ body wt) as compared with aminogram of cord blood. The base lines of cord blood are provided from papers by Ghadimi and Pecora [12] and Lindblad et al. [23].

With all these shortcomings in mind, the question may be asked why the baneful effects of these "irrational solutions" are apparent in only a small proportion of patients undergoing parenteral alimentation, and why a modality using such solutions has won any degree of acceptance at all. Perhaps the virtues of the concept and technique of total parenteral alimentation, as developed by Dudrick and others, greatly compensate for the shortcomings of one component of the infusate; the clinical material generally consists of gravely ill patients who present the physician with little therapeutic choice, and in whom bare survival is generally considered a noteworthy achievement; then, too, only short term results of parenteral alimentation are available to us so far. Finally, credit must be given to human biochemical stamina in coping both with amino acid deprivation and with its ill tailored remedy.

\section{References and Notes}

1. AdiBI, S. A.: Interrelationship between level of amino acids in plasma and tissues during starvation. Amer. J. Physiol., 221: 829 (1971).

2. Arhammar, G., Bjornesto, K. B., Jagenburg, R., and MELLANDER, O.: Plasma and erythrocyte amino acids during treatment of protein calorie malnutrition. Acta Paed. Scand., 61: 145 (1972).
3. Biedl, A., AND Kraus, R.: Ueber intravenose traubenzucker infusionen an menschen. Wien. Klin. Wchschr. 9: 55 (1896).

4. Bowie, M. D., Brinkman, G. L., and Hansen, J. D. L.: Acquired disaccharide intolerance in malnutrition. J. Pediat., 66: 1083 (1965).

5. Chan, J. C. M., Malekzadeh, M., and Hurlex, J.: pH and titratable acidity of amino acid mixtures used in hyperalimentation. J. Amer. Med. Ass., 220: 1119 (1972).

6. Donaldson, H. H.: The Rat, Ed. 2. Mems Wistar Institute, Philadelphia, (1924).

7. Doolan, P. D., Harper, H. A., Hutchin, M. E., and Alpen, E. L.: The renal tubular response to amino acid loading. J. Clin. Invest., 35: 888 (1956).

8. Ghadrmi, H., Abaci, F., Kumar, S., and Rathi, M.: Biochemical aspects of intravenous alimentation. Pediatrics, 48: 955 (1971).

9. Ghadimi, H., AND Kumar, S.: High ammonia content of protein hydrolyzate. Biochem. Med., 5: 548 (1971).

10. Ghadimi, H., Kumar, S., and Abaci, F.: Studies on monosodium glutamate ingestion. I. Biochemical explanation of Chinese Restaurant Syndrome. Biochem. Med., 5: 447 (1971).

11. Gradimi, H., Kumar, S., And Abaci, F.: Endogenous amino acid loss and its significance in infantile diarrhea. Pediat. Res., in press.

12. Ghadimi, H., ANd Pecora, P.: Free amino acids of cord plasma as compared with maternal plasma during pregnancy. Pediatrics, 33: 500 (1964).

13. Growth and Development of the Child. White House Conference on Child Health and Protection. Part II. Anatomy and Physiology, p. 19. (Century, New York, 1933). 
14. Harper, A. E.: Amino acid balance and food intake regula. tion. In: H. C. Meng and D. H. Low: Parenteral Nutrition, p. 181. (Charles C Thomas, Publisher, Springfield, Ill., 1970).

15. Heird, W. C., Nicholson, J. F., Driscoll, J. M., JR., Schullinger, J. N., ANd Winters, R. W.: Hyperammonemia resulting from intravenous alimentation using a mixture of synthetic L-amino acids: A preliminary report. J. Pediat., 81 : 162 (1972).

16. Heller, L.: Clinical and experimental studies on complete parenteral nutrition. Scand. J. Gastroent. 4 (Suppl. 3): 9 (1969).

17. Herbert, J. D., Coulson, R. A., and Hernandez, T.: Free amino acids in the caiman and rat. Comp. Biochem. Physiol., 17: 583 (1966).

18. Ho MAN KYOK, R.: Letter to the Editor. New Engl. J. Med., 278: 796 (1968)

19. Kinnear, A. A., AND Pretorius, P. J.: Liver functions in kwashiorkor. Brit. Med. J., 1: 152B, 1956.

20. Knudsen, K. B., Bellamy, H. M., Lecoeg, F. R., Bradley, E. M., AND WELSH, J. P.: The influence of fasting and refeeding on jejunal disaccharidases. South. Soc. Clin. Invest., January 28 (1966).

21. Lasichak, A. G., and Levey, S.: Glutamic acid and vomiting in dogs: Its administration into the portal system and extremity veins. Proc. Soc. Exp. Biol. Med., 70: 74 (1949).

22. Levey, S.. Harroun, J. E., and Smyth, C. J.: Serum glutamic acid levels and the occurrence of nausea and vomiting after the intravenous administration of amino acid mixtures. J. Lab. Clin. Med., 34: 1238 (1949).

23. Lindblad, B. S., and Zetrerstrom, R. The venous plasma free amino acid levels of mother and child during delivery. Acta Paed. Scand., 57: 195 (1968).

24. McFarlane, H., Adcock, K. J., Cooke, A., Ogbeide, M. I., Adeshina, H., Taylor, G. O., Reddy, S., Gurney, J. M., and Mordie, J. A.: Biochemical assessment of protein-calorie malnutrition. Lancet, $i: 392$ (1969).

25. Munro, $H$. N.: Free amino acid pools and their role in regulation. In: H. N. Munro: Mammalian Protein Metabolism, Vol. IV, p. 302. (Academic Press, New York, 1970).

26. NeAme, K. D., and Wrseman, G.: The transamination of glutamic and aspartic acids during absorption by the small intestine in the dog in vivo. J. Physiol., 135: 442 (1957).

27. Picou, D., Halliday, D., and Garrow, J. S.: Total body protein collagen and noncollagen protein in infantile protein malnutrition. Clin. Sci., 30: 345 (1966).

28. Ranananthan, M. K.: Biochemical changes in serum in nutritional edema. Indian J. Med. Res., 43: 517 (1955).

29. Saunders, S. J., Truswell, A. S., Barbezat, G. O., Wittman, W., AND Hansen, J. D. L.: Plasma free amino acid pattern in protein-calorie malnutrition. Lancet, $i i: 795$ (1967).
30. Schaumburg, H. H., ANd Byck, R.: Letter, SIN CIB-SYN Accent on glutamate. New Engl. J. Med., 279: 105 (1968).

31. Schendel, H. E., Hansen, J. D. L., and Brock, J. F.: The biochemical assessment of protein malnutrition status. I. Marginal hypoalbuminaemia. II. Serum cholinesterase. S. Afr. J. Lab. Clin. Med., 8: 23 (1962).

32. Sruvis, S. E., And Paragas, P. V., JR.: Fatal hyperalimentation syndrome. Animal studies. J. Lab. Clin. Med., 78: 918 (1971).

33. Simmons, W. K.: Urinary urea nitrogen/creatinine ratio as indicator of recent protein intake in field studies. Amer. J. Clin. Nutr., 25: 539 (1972).

34. Snyderman, S. E., Holt, L. E., Jr., Norton, P. M., Roitman, E., and Phansalkar, S. V.: The plasma aminogram. I. Influence of the level of protein intake and a comparison of whole protein and amino acid diets. Pediat. Res., 2: 131 (1968).

35. WALKER, F. A.: Ammonia in fibrin hydrolysates. Letter to the Editor. New Engl. J. Med., 285: 1324 (1971).

36. Waterlow, J. C.: The assessment of protein nutrition and metabolism in the whole animal, with special reference to man. In: H. N. Munro. Mammalian Protein Metabolism, Vol. III, p. 382. (Academic Press, New York, 1969).

37. Waterlow, J. C., Cravioto, J., and Stephen, J. M. L.: Protein malnutrition in man. Advan. Protein Chem., 15: 131 (1960).

38. Waterlow, J. G., Cravioto, J., and Stephen, J. M. L.: Protein malnutrition in man. Advan. Protein Chem., 15: 354 (1960).

39. Waterlow, J. C., Cravioto, J., and Stephen, J. M. L.: Protein malnutrition in man. Advan. Protein Chem., 15: 355 (1960).

40. Watson, E. H., and Lowrey, G. H.: Growth and Development of Children, Ed. 4, p. 177. (Yearbook Medical Publishers, Chicago, 1962).

41. Webster, L. T., and Davidson, C. S.: Cirrhosis of the liver. Impending hepatic coma and increased blood ammonium concentrations during protein hydrolysate infusions. J. Lab. Clin. Med., 50: 1 (1957).

42. Whitehead, R. G.: Hydroxyproline creatinine ratio. Index of nutritional status and rate of growth. Lancet, $i i: 567$ (1965).

43. Widdowson, L. M., And Srray, C. M.: Clinical development in utero. Arch. Dis. Childhood, 26: 205 (1951).

44. Wohl, M. G., AND GoodharT, R. S.: Modern Nutrition in Health and Disease, p. 12. (Lea \& Febiger, Philadelphia, 1968).

45. Baxter Laboratories, Inc., Morton Grove, Ill.

46. McGaw Laboratories, Inc., Glendale, Calif.

47. Requests for reprints should be addressed to: H. GHadimr, M.D., Methodist Hospital of Brooklyn, 506 Sixth Street, Brooklyn, N. Y. 11215 (USA).

48. Accepted for publication November 29, 1972. 